\title{
Immediate effects of photobiomodulation with low-level laser therapy on muscle performance: an integrative literature review
}

\author{
Vanessa Mouffron Novaes Alves' \\ https://orcid.org/0000-0002-1974-366X \\ Renata Maria Moreira Moraes Furlan ${ }^{1}$ \\ https://orcid.org/0000-0001-7588-9316
}

Andréa Rodrigues Motta ${ }^{1}$

https://orcid.org/0000-0002-1582-3785

Universidade Federal de Minas Gerais UFMG, Belo Horizonte, Minas Gerais, Brasil.

Conflict of interests: Nonexistent

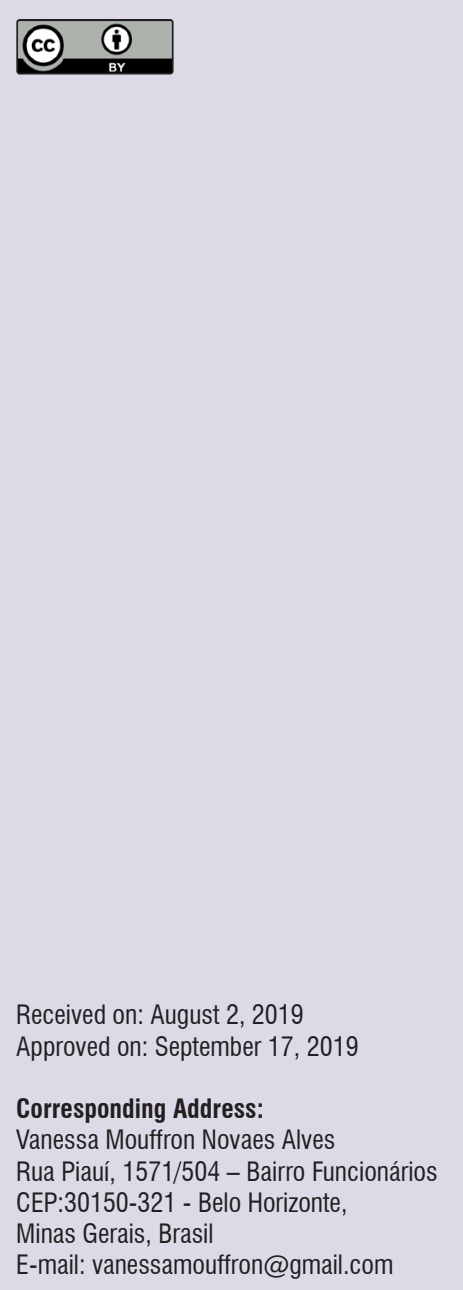

\section{ABSTRACT}

Purpose: to analyze the influence of low-level laser on muscle performance and to identify the most used dosimetric parameters.

Methods: the search for articles was carried out on the PubMed, BVS, Web of Science and SciELO platforms. The articles selected were original ones, with available abstracts and that evaluated the use of photobiomodulation on muscular performance. The data were analyzed according to the author, year of publication, sample, place of application, parameters evaluated, wavelength, dosimetry used and results found.

Results: the final sample consisted of 27 articles published between 2008 and 2017. The sample size in the studies ranged from 8 to 60 individuals, aged from 17 to 70 years. A greater use of infrared wavelength, with punctual applications carried out in the path of the muscle, was observed. Regarding the dose, there was a variation from 0.24 to 50 joules per point. Of the total, only 5 (18.5\%) studies had not found significant answers for the considered variables.

Conclusion: most of the studies pointed out that low-level laser can improve muscle performance. The methodology used in the work was diversified, rendering data compilation difficult, being impossible to set the ideal parameters for this purpose.

Keywords: Low-Level Light Therapy; Muscle Strength; Stomatognathic System; Speech, Language and Hearing Sciences 


\section{INTRODUCTION}

The effects of phototherapy on the muscular system have been the object of study of professionals dedicated to muscle rehabilitation and sports performance ${ }^{1}$. Among the main findings reported in the literature are the performance improvement ${ }^{1}$, fatigue reduction ${ }^{2}$, greater strength gain ${ }^{3}$ and relaxation ${ }^{4,5}$.

These results are believed to occur due to the biomodulatory action that light can exert on the body. Through the so-called photochemical effect, the light energy absorbed by chromophores is transformed into chemical energy, which produces local and/ or systemic biological effects in the organism 6 . For red and infrared wavelengths, the absorption occurs mainly in the mitochondria and directly intervened in the cellular respiration process, allowing the immediate influx of oxygen, the resumption of the respiratory chain and, consequently, the acceleration of intracellular adenosine triphosphate (ATP) synthesis ${ }^{7,8}$. Given that muscle activity requires high energy expenditure, it is believed that resources which optimize ATP synthesis may also positively intervene in the functional performance ${ }^{1}$.

The effects of laser on the organism are mainly determined by the dosimetric parameters selected by the therapist. Dosimetry is currently the biggest challenge in laser therapy and, in the scientific literature, the data about the best irradiation parameters are still quite controversial, with no specific well established protocols for each objective. Proper selection of physical variables, such as power, dose, energy density, irradiance, energy by points, emission type, application mode and wavelength are fundamental to achieve the desired results 9 .

Until now, only one study ${ }^{10}$ has evaluated the effects of photobiomodulation on the performance of an orofacial muscle. Despite the lack of evidence, clinical practice has shown that the association of this treatment tool with the orofacial motricity therapy improves the performance during the execution of the myofunctional and myotherapy exercises, and it is a field with great potential for future research.

Therefore, the objective of this work was to analyze studies on the influence of low-level laser on muscle performance and to identify the most commonly used dosimetric parameters (wavelength, dose, number of points, place of application).

\section{METHODS}

This is an integrative literature review, which involved the following stages: elaboration of the guiding questions, establishment of the keywords and the inclusion and exclusion criteria of the articles, search, selection and critical analysis of the studies.

The guiding questions were: Does the application of low-level laser influence the muscle performance? What is the most used wavelength? What is the most commonly used dose and application modes? Search expressions were created with descriptors and keywords related to photobiomodulation and muscle performance and are described in Figure 1. Searches were performed on the PubMed, BVS, Web of Science and SCIELO platforms.

\begin{tabular}{|c|c|}
\hline Database & Seach Terms \\
\hline BVS and SciELO & $\begin{array}{l}\text { tw:(("Lasers Semicondutores" OR "Lasers de Diodo" OR "Lasers de Arsenieto de Gálio e Alumínio" OR "Lasers de Arsenieto } \\
\text { de Gálio" OR "Terapia com Luz de Baixa Intensidade" OR laserterapia OR "Terapia a Laser de Baixa Intensidade" OR "Irradiação } \\
\text { a Laser de Baixa Intensidade" OR "Terapia a Laser de Baixa Potência" OR "Bioestimulação a Laser" OR "Irradiação a Laser de } \\
\text { Baixa Potência" OR "Laser Biostimulation" OR "LLLT" OR lasers OR "Raios Laser" OR laser OR fototerapia OR "Láseres de } \\
\text { Semiconductores" OR "Terapia por Luz de Baja Intensidad" OR "RayosLáser" OR fototerapia OR "Lasers, Semiconductor" } \\
\text { OR "Low-Level Light Therapy" OR "Laser Biostimulation" OR "Laser Phototherapy" OR "LowLevel Laser Therapy" OR "Low- } \\
\text { Level Laser Therapy" OR "PhotobiomodulationTherapy" OR phototherapy) AND ("Músculo Esquelético" OR "Desenvolvimento } \\
\text { Musculoesquelético" OR "Força Muscular" OR "Contração Muscular" OR "Desarrollo Musculoesquelético" OR "Fuerza } \\
\text { Muscular" OR "Contracción Muscular" OR "Muscle, Skeletal" OR "MusculoskeletalDevelopment" OR "MuscleStrength" OR } \\
\text { "MuscleContraction")) }\end{array}$ \\
\hline $\begin{array}{l}\text { PubMed and Web of } \\
\text { Science }\end{array}$ & $\begin{array}{l}\text { ("LLLT" OR "Lasers, Semiconductor" OR "Low-Level Light Therapy" OR "Laser Biostimulation" OR "Laser Phototherapy" OR } \\
\text { "Low Level Laser Therapy" OR "Low-Level Laser Therapy" OR "Photobiomodulation Therapy" OR phototherapy) AND ("Muscle, } \\
\text { Skeletal" OR "Musculoskeletal Development" OR "Muscle Strength" OR "Muscle Contraction") }\end{array}$ \\
\hline
\end{tabular}

Figure 1. Data search strategy 
The selection included articles that met the following criteria: be original; have available abstract and have, among its objectives, the one to evaluate the effects of low-level laser on muscle performance through parameters related to endurance, strength and fatigue.

Exclusion criteria were the exclusive use of other therapeutic light sources, such as the Light Emitting Diode (LED), the pulsed light and the high power laser. Articles that investigated the secondary improvement of muscle performance in relation to laser analgesic or relaxing action were also not considered in the analysis.

The selection of articles was made independently by two speech-language therapists by reading the abstracts. Data management was performed in a spreadsheet prepared in Microsoft Excel 2016 that allowed the evaluators two answers for selection: yes or no. The articles that received "yes" from both evaluators were included for full reading. Those who got a "no" answer from both researchers were excluded from the study. It was established that, if there were divergences of answers between the two evaluators, a consensus meeting would be held and, if the impasse remained, a third evaluator would be consulted.

The material analysis was performed in two stages. In the first, the duplicate references in the consulted databases were eliminated and, by reading the titles and abstracts, the articles that did not meet the established objectives were excluded. In the second stage, the previously selected articles were obtained and read in full, being discarded those that met the exclusion criteria. The data analysis stages are shown in Figure 2.

From the articles selected for analysis of the results and discussion of the findings, author and year of publication, objectives, sample and age range, wavelength used, dose, number of points, place of application and results were recorded.

\section{LITERATURE REVIEW}

A total of 1,255 articles were initially found. After consensus between the two evaluators, 36 articles



Figure 2. Articles selection stages

were included for full reading, of which nine were excluded because they had used other light sources or had muscle performance related to the laser analgesic effect. Figure 3 presents a summary of the analyzed information from the articles. 


\begin{tabular}{|c|c|c|c|c|}
\hline $\begin{array}{c}\text { Authors and } \\
\text { year }\end{array}$ & Objectives/Sample & Wavelength & $\begin{array}{l}\text { Dose/number of points/place } \\
\text { of application/total dose }\end{array}$ & Results \\
\hline $\begin{array}{l}\text { Leal Junior e } \\
\text { Lopes-Martins, } \\
2008^{(11)}\end{array}$ & $\begin{array}{l}\text { To investigate the effects of laser on muscle } \\
\text { fatigue attenuation in } 12 \text { healthy men aged } \\
\text { from } 18 \text { to } 35 \text { years. }\end{array}$ & Red & $\begin{array}{l}5 \mathrm{~J} \text { per point }-4 \text { points on the } \\
\text { biceps }-20 \mathrm{~J} \text { in total. }\end{array}$ & $\begin{array}{l}\text { There was an increase in the average number of } \\
\text { repetitions in the irradiated group in relation to } \\
\text { the placebo one. There were no changes of the } \\
\text { maximum voluntary contraction and in the lactate } \\
\text { levels. }\end{array}$ \\
\hline $\begin{array}{l}\text { Leal Junior et al., } \\
\qquad 2009^{(12)}\end{array}$ & $\begin{array}{l}\text { To investigate the effects on muscle fatigue } \\
\text { in ten healthy men aged from } 18 \text { to } 36 \text { years. }\end{array}$ & Infrared & $\begin{array}{l}5 \mathrm{~J} \text { per point }-4 \text { points on the } \\
\text { biceps }-20 \mathrm{~J} \text { in total. }\end{array}$ & $\begin{array}{l}\text { There was an increase in the average number of } \\
\text { repetitions in the irradiated group in relation to the } \\
\text { placebo one. There were no changes in the lactate } \\
\text { levels and execution time. }\end{array}$ \\
\hline $\begin{array}{l}\text { Leal Junior et al., } \\
\qquad 2009^{(13)}\end{array}$ & $\begin{array}{l}\text { To compare the effects of laser versus LED on } \\
\text { the muscle fatigue in eight healthy men aged } \\
\text { from } 17 \text { to } 20 \text { years. }\end{array}$ & Infrared & $\begin{array}{c}6 \mathrm{~J} \text { at each point - } 2 \text { points } \\
\text { over the rectus femoris - } \\
12 \mathrm{~J} \text { total. }\end{array}$ & $\begin{array}{l}\text { There was a reduction in creatine kinase levels } \\
\text { in the group irradiated with LED. There was no } \\
\text { improvement of muscle performance and lactate } \\
\text { levels in the groups. }\end{array}$ \\
\hline $\begin{array}{l}\text { Leal Junior et al., } \\
\qquad 2009^{(14)}\end{array}$ & $\begin{array}{l}\text { To investigate the effects on the biochemical } \\
\text { markers of muscle recovery after high } \\
\text { intensity exercise in } 20 \text { healthy men aged } \\
\text { from } 18 \text { to } 25 \text { years. }\end{array}$ & Infrared & $\begin{array}{l}4 \mathrm{~J} \text { at each point (volleyball } \\
\text { players), } 3 \mathrm{~J} \text { at each point } \\
\text { (soccer players) - } 5 \text { points } \\
\text { on each leg over the rectus } \\
\text { femoris. } 20 \mathrm{~J} \text { and } 15 \mathrm{~J} \text { total } \\
\text { respectively. } \\
\end{array}$ & $\begin{array}{l}\text { There was an improvement in creatine kinase and } \\
\text { lactate levels in the irradiated groups in relation to } \\
\text { the placebo one. There was no effect on muscle } \\
\text { performance. }\end{array}$ \\
\hline $\begin{array}{l}\text { Baroni et al., } \\
2010^{(15)}\end{array}$ & $\begin{array}{l}\text { To investigate the effects of laser on indirect } \\
\text { markers of the muscle damage in } 36 \text { healthy } \\
\text { men aged from } 19 \text { to } 35 \text { years. }\end{array}$ & Infrared & $\begin{array}{l}30 \mathrm{~J} \text { per point }-6 \text { points on the } \\
\text { quadriceps - } 180 \mathrm{~J} \text { total. }\end{array}$ & $\begin{array}{l}\text { There was an improvement of the blood markers } \\
\text { and a smaller decrease in MVC in the irradiated } \\
\text { groups in relation to the placebo one. There was } \\
\text { no difference in the muscle pain. }\end{array}$ \\
\hline $\begin{array}{l}\text { Leal Junior et al., } \\
\qquad 2010^{(16)}\end{array}$ & $\begin{array}{l}\text { To evaluate the effects of laser on muscle } \\
\text { performance and fatigue in } 14 \text { healthy men } \\
\text { aged from } 18 \text { to } 25 \text { years. }\end{array}$ & Red & $\begin{array}{l}2.4 \mathrm{~J} \text { per point } 5 \text { points over } \\
\text { tibialis anterior }-12 \mathrm{~J} \text { total. }\end{array}$ & $\begin{array}{l}\text { The peak torque was higher after laser application. } \\
\text { There were no effects on the fatigue index. }\end{array}$ \\
\hline $\begin{array}{l}\text { Leal Junior et al., } \\
\qquad 2010^{(2)}\end{array}$ & $\begin{array}{l}\text { To investigate the effects on muscle } \\
\text { performance, fatigue and muscle recovery in } \\
\text { nine healthy men aged from } 18 \text { to } 20 \text { years. }\end{array}$ & Infrared & $\begin{array}{l}30 \mathrm{~J} \text { per point }-2 \text { points on the } \\
\text { biceps - } 60 \mathrm{~J} \text { total.. }\end{array}$ & $\begin{array}{l}\text { There was an increase in the number of repetitions, } \\
\text { the time before exhaustion and in the biochemical } \\
\text { markers in the irradiated group in relation to the } \\
\text { placebo one. }\end{array}$ \\
\hline $\begin{array}{l}\text { Ferraresi et al., } \\
\qquad 2011^{(17)}\end{array}$ & $\begin{array}{l}\text { To test the effects on strength gain in } 36 \\
\text { healthy men aged from } 18 \text { to } 28 \text { years. }\end{array}$ & Infrared & $\begin{array}{l}3.6 \mathrm{~J} \text { per point }-7 \text { points on the } \\
\text { quadriceps }-25.2 \mathrm{~J} \text { total. }\end{array}$ & $\begin{array}{l}\text { There was an increase in muscle strength gain } \\
\text { in the irradiated group when compared to the } \\
\text { placebo and control ones. There was no difference } \\
\text { in the thigh perimeter. }\end{array}$ \\
\hline $\begin{array}{l}\text { Almeida et al., } \\
\qquad 2012^{(18)}\end{array}$ & $\begin{array}{l}\text { To investigate the effect on the muscle fatigue } \\
\text { and to compare the } R \text { and IR wavelengths in } \\
\text { ten healthy participants aged from } 19 \text { to } 27 \\
\text { years. }\end{array}$ & $\begin{array}{l}\text { Red or } \\
\text { Infrared }\end{array}$ & $\begin{array}{l}5 \mathrm{~J} \text { per point }-4 \text { points on the } \\
\text { biceps - } 20 \mathrm{~J} \text { total. }\end{array}$ & $\begin{array}{l}\text { The mean maximum strength was higher for } R \text { and } \\
\text { IR without difference between them. There was no } \\
\text { effect on the mean of the strengths. }\end{array}$ \\
\hline $\begin{array}{l}\text { Marchi et al., } \\
2012^{(19)}\end{array}$ & $\begin{array}{l}\text { To evaluate the effects on the exercise } \\
\text { performance, oxidative stress and muscle } \\
\text { condition in } 22 \text { healthy men aged from } 20 \text { to } \\
25 \text { years. }\end{array}$ & Infrared & $\begin{array}{c}30 \mathrm{~J} \text { per point - } 12 \text { points on } \\
\text { the lower limb (quadriceps, } \\
\text { hamstring and gastrocnemius) } \\
-360 \mathrm{~J} \text { total. }\end{array}$ & $\begin{array}{l}\text { There was an improvement of the performance in } \\
\text { the aerobic exercise, in the oxidative stress and } \\
\text { of the biochemical markers of muscle damage in } \\
\text { the irradiated group when compared to the control } \\
\text { one. }\end{array}$ \\
\hline $\begin{array}{l}\text { Vieira et al., } \\
2012^{(20)}\end{array}$ & $\begin{array}{l}\text { To investigate whether laser associated with } \\
\text { endurance training increases the muscle } \\
\text { performance in } 45 \text { healthy women aged from } \\
18 \text { to } 28 \text { years. } \\
\end{array}$ & Infrared & $\begin{array}{l}3.6 \mathrm{~J} \text { per point }-5 \text { points on the } \\
\text { quadriceps - } 18 \mathrm{~J} \text { in total. }\end{array}$ & $\begin{array}{l}\text { There was fatigue resistance increase in the } \\
\text { irradiated group when compared to the control } \\
\text { one. There were no significant changes in the } \\
\text { respiratory capacity and muscle work. }\end{array}$ \\
\hline $\begin{array}{l}\text { Higashi et al., } \\
\text { 2013(21) }\end{array}$ & $\begin{array}{l}\text { To evaluate the effects on the muscle fatigue } \\
\text { in } 20 \text { healthy women aged from } 18 \text { to } 25 \\
\text { years. }\end{array}$ & Infrared & $\begin{array}{l}7 \mathrm{~J} \text { per point - } 8 \text { points on the } \\
\text { biceps - } 56 \mathrm{~J} \text { in total. }\end{array}$ & $\begin{array}{l}\text { There was no difference in the number of } \\
\text { repetitions, lactate indexes and electromyographic } \\
\text { fatigue. }\end{array}$ \\
\hline $\begin{array}{l}\text { Muñoz et al., } \\
2013^{(10)}\end{array}$ & $\begin{array}{l}\text { To compare the effect of laser versus LED on } \\
\text { the masseter muscle activity in ten healthy } \\
\text { men with a mean age of } 28 \pm 6 \text { years. }\end{array}$ & Infrared & $\begin{array}{l}0.8 \mathrm{~J} \text { per point }-8 \text { points on the } \\
\text { masseter. }-6.4 \mathrm{~J} \text { in total. }\end{array}$ & $\begin{array}{l}\text { There was an increase of the muscle activity in the } \\
\text { irradiated groups when compared to the control } \\
\text { one. There was no difference in strength, fatigue } \\
\text { time and lactate levels. }\end{array}$ \\
\hline $\begin{array}{l}\text { Toma et al., } \\
2013^{(22)}\end{array}$ & $\begin{array}{l}\text { To investigate the effects of laser on the } \\
\text { muscle fatigue in } 24 \text { healthy women aged } \\
\text { from } 60 \text { to } 70 \text { years. }\end{array}$ & Infrared & $\begin{array}{c}7 \mathrm{~J} \text { per point - } 8 \text { points over } \\
\text { dominant rectus femoris - } 56 \\
\mathrm{~J} \text { in total. }\end{array}$ & $\begin{array}{l}\text { There was an increase in the number of repetitions } \\
\text { in the irradiated group in relation to the placebo } \\
\text { one. There was no effect on electromyographic } \\
\text { fatigue. }\end{array}$ \\
\hline $\begin{array}{l}\text { Alves et al., } \\
\text { 2014(23) }\end{array}$ & $\begin{array}{l}\text { To evaluate the immediate effects on } \\
\text { the cardiorespiratory performance and } \\
\text { electromyographic fatigue in } 18 \text { healthy } \\
\text { participants aged from } 18 \text { to } 30 \text { years. }\end{array}$ & Infrared & $\begin{array}{c}14 \mathrm{~J} \text { per point - } 3 \text { points over } \\
\text { the quadriceps femoris and } \\
1 \text { point of the gastrocnemius - } \\
56 \mathrm{~J} \text { in total. }\end{array}$ & $\begin{array}{l}\text { There was an improvement of the cardiovascular } \\
\text { efficiency. The electromyographic fatigue showed } \\
\text { no changes. }\end{array}$ \\
\hline $\begin{array}{l}\text { Felismino et al., } \\
2014^{(24)}\end{array}$ & $\begin{array}{l}\text { To investigate the effects on markers of } \\
\text { muscle damage and strength performance in } \\
22 \text { healthy men aged from } 20 \text { to } 35 \text { years. }\end{array}$ & Infrared & $\begin{array}{l}1 \mathrm{~J} \text { per point }-4 \text { points on the } \\
\text { biceps }-4 \mathrm{~J} \text { bilaterally in total. }\end{array}$ & $\begin{array}{l}\text { There was a decrease of the creatine kinase levels } \\
\text { in the irradiated group compared to the placebo } \\
\text { one. There was no effect on the recovery of the } \\
\text { maximum strength performance. }\end{array}$ \\
\hline
\end{tabular}




\begin{tabular}{|c|c|c|c|c|}
\hline $\begin{array}{c}\text { Authors and } \\
\text { year }\end{array}$ & Objectives/Sample & Wavelength & $\begin{array}{c}\text { Dose/number of points/place } \\
\text { of application/total dose }\end{array}$ & Results \\
\hline $\begin{array}{l}\text { Maciel et al., } \\
\text { 2014(25) }\end{array}$ & $\begin{array}{l}\text { To investigate laser action on the muscle } \\
\text { performance and fatigue in } 12 \text { healthy } \\
\text { women aged from } 18 \text { to } 30 \text { years. }\end{array}$ & Infrared & $\begin{array}{c}0.81 \mathrm{~J} \text { per point - } \\
\text { "approximately } 29 \text { points" over } \\
\text { the tibialis anterior. }\end{array}$ & $\begin{array}{l}\text { There was an increase in torque in the evaluation } \\
\text { of endurance after laser. There was no change in } \\
\text { the peak strength, electromyographic fatigue and } \\
\text { lactate levels. }\end{array}$ \\
\hline $\begin{array}{l}\text { Vieira et al, } \\
\text { 2014(26) }\end{array}$ & $\begin{array}{l}\text { To investigate the effects on muscle fatigue } \\
\text { in seven healthy men with a mean age of } 21 \\
\pm 3 \text { years. }\end{array}$ & Infrared & $\begin{array}{c}4 \mathrm{~J} \text { per point } \\
\text { - Rectus femoris: } 3 \text { points } \\
\text { ( } 12 \mathrm{~J} \text { in total) } \\
\text { - Vastus medialis: } 1 \text { point } \\
(4 \mathrm{~J} \text { in total) } \\
\text { - Vastus lateralis: } 1 \text { point } \\
(4 \mathrm{~J} \text { in total). } \\
\text { Each protocol was repeated } \\
3 \text { times during the exercise: } \\
60 \mathrm{~J} \text { in total. }\end{array}$ & $\begin{array}{l}\text { It was observed increase of the number of } \\
\text { repetitions and decrease of the electromyographic } \\
\text { fatigue after laser application. }\end{array}$ \\
\hline $\begin{array}{l}\text { Baroni et al., } \\
2015^{(27)}\end{array}$ & $\begin{array}{l}\text { To investigate the effects on the strength } \\
\text { gain and muscle hypertrophy in } 30 \text { healthy } \\
\text { participants aged from } 20 \text { to } 35 \text { years.. }\end{array}$ & Infrared & $\begin{array}{c}30 \mathrm{~J} \text { per point }-8 \text { points on the } \\
\text { quadriceps - } 240 \mathrm{~J} \text { in total. }\end{array}$ & $\begin{array}{l}\text { There was greater strength gain (MVC) and greater } \\
\text { muscle hypertrophy in the irradiated group when } \\
\text { compared to placebo one. }\end{array}$ \\
\hline $\begin{array}{l}\text { Kakihata et al., } \\
\quad 2015^{(28)}\end{array}$ & $\begin{array}{l}\text { To evaluate the effects on the fatigue and the } \\
\text { muscle power in } 22 \text { sedentary women with a } \\
\text { mean age of } 21.21 \pm 2.8 \text { years. }\end{array}$ & Red & $\begin{array}{l}0.24 \mathrm{~J} \text { per point }-8 \text { points on } \\
\text { the triceps surae }-1.92 \mathrm{~J} \text { in } \\
\text { total. }\end{array}$ & $\begin{array}{l}\text { No changes were found in the jump height, fatigue } \\
\text { index and delayed onset muscle soreness. }\end{array}$ \\
\hline $\begin{array}{l}\text { Bublitz et al., } \\
2016^{(29)}\end{array}$ & $\begin{array}{l}\text { To evaluate the effects on functional capacity, } \\
\text { subjective perception of exertion and blood } \\
\text { lactate levels in } 20 \text { hospitalized participants } \\
\text { with heart failure aged from } 35 \text { to } 65 \text { years. } \\
\end{array}$ & Infrared & $\begin{array}{l}4 \mathrm{~J} \text { per point }-7 \text { points on the } \\
\text { quadriceps - } 28 \mathrm{~J} \text { in total. }\end{array}$ & $\begin{array}{l}\text { There was a reduction of the exertion perception } \\
\text { in the irradiated group in relation to the placebo } \\
\text { one. There was no difference in the submaximal } \\
\text { function test and in the lactate levels. }\end{array}$ \\
\hline $\begin{array}{l}\text { Souza et al, } \\
2016^{(30)}\end{array}$ & $\begin{array}{l}\text { To evaluate the immediate effects on } \\
\text { neuromuscular performance and fatigue in } \\
60 \text { healthy participants aged from } 18 \text { to } 28 \\
\text { years. }\end{array}$ & Infrared & $\begin{array}{l}5 \mathrm{~J} \text { per point }-5 \text { points on the } \\
\text { soleus muscle }-25 \mathrm{~J} \text { in total. }\end{array}$ & $\begin{array}{l}\text { There was a reduction in the fatigue index by } \\
\text { dynamometry in the irradiated group in relation } \\
\text { to the placebo one. There was no difference in } \\
\text { median frequency. }\end{array}$ \\
\hline $\begin{array}{l}\text { Toma et al., } \\
2016^{(31)}\end{array}$ & $\begin{array}{l}\text { To evaluate the effects of the laser association } \\
\text { with muscle training on strength gain in } 48 \\
\text { healthy women aged from } 60 \text { to } 70 \text { years. }\end{array}$ & Infrared & $\begin{array}{l}7 \mathrm{~J} \text { per point - } 8 \text { points on the } \\
\text { quadriceps }-56 \mathrm{~J} \text { in total. }\end{array}$ & $\begin{array}{l}\text { There was an improvement of the performance } \\
\text { and in the lactate indexes in the irradiated group } \\
\text { in relation to the placebo one. There was no } \\
\text { difference in the fatigue. }\end{array}$ \\
\hline $\begin{array}{l}\text { Vanin et al., } \\
2016^{(32)}\end{array}$ & $\begin{array}{l}\text { To evaluate the medium-term effects of } \\
\text { laser on muscle recovery, performance } \\
\text { improvement, and to compare different doses } \\
\text { in } 28 \text { healthy men aged from } 18 \text { to } 35 \text { years. }\end{array}$ & Infrared & $\begin{array}{c}\text { Group } A=10 \mathrm{~J} \text { per point - } \\
6 \text { points on the quadriceps - } \\
60 \mathrm{~J} \text { in total. } \\
\text { Group } \mathrm{B}=30 \mathrm{~J} \text { per point - } \\
6 \text { points on the quadriceps - } \\
180 \mathrm{~J} \text { in total. } \\
\text { Group } \mathrm{C}=50 \mathrm{~J} \text { per point - } \\
6 \text { points on the quadriceps - } \\
300 \mathrm{~J} \text { in total. }\end{array}$ & $\begin{array}{l}\text { Group A increased the MVC compared to the } \\
\text { placebo one in the } 24 \text { to } 96 \mathrm{~h} \text { reevaluations. Group } \\
\mathrm{C} \text { improved MVC at the time immediately after and } \\
24 \mathrm{~h} \text { and the creatine kinase and IL- } 6 \text { levels. }\end{array}$ \\
\hline $\begin{array}{l}\text { Vassão et al., } \\
2016^{(33)}\end{array}$ & $\begin{array}{l}\text { To investigate the effects of } \\
\text { photobiomodulation on muscle fatigue and } \\
\text { performance in } 30 \text { healthy women aged from } \\
60 \text { to } 70 \text { years. } \\
\end{array}$ & Infrared & $\begin{array}{c}7 \mathrm{~J} \text { per point - } 8 \text { points over the } \\
\text { dominant rectus femoris - } \\
56 \mathrm{~J} \text { in total. }\end{array}$ & $\begin{array}{l}\text { Improvement in the electromyographic fatigue } \\
\text { and lactate levels was observed, with no effect on } \\
\text { muscle strength. }\end{array}$ \\
\hline $\begin{array}{l}\text { Zagatto et al., } \\
2016^{(34)}\end{array}$ & $\begin{array}{l}\text { To evaluate the effects of five days of laser } \\
\text { therapy on muscle lesion markers and the } \\
\text { performance in } 20 \text { healthy men with a mean } \\
\text { age of } 15.4 \pm 1.2 \text {. }\end{array}$ & Infrared & $\begin{array}{l}3 \mathrm{~J} \text { per point - } 8 \text { points on the } \\
\text { abductor muscle - } 24 \mathrm{~J} \text { in total. }\end{array}$ & $\begin{array}{l}\text { There was an improvement in the performance of } \\
\text { the jumps, without effect on the swimming task } \\
\text { and on the biochemical markers of muscular } \\
\text { lesion. }\end{array}$ \\
\hline $\begin{array}{l}\text { Marchi et al., } \\
2017^{(35)}\end{array}$ & $\begin{array}{l}\text { To compare the effects of three } \\
\text { photobiomodulatory devices on muscle } \\
\text { performance and post workout recovery in } \\
40 \text { healthy men aged from } 18 \text { to } 35 \text { years. }\end{array}$ & Infrared & $\begin{array}{l}30 \mathrm{~J} \text { per point }-6 \text { points on the } \\
\text { quadriceps }-180 \mathrm{~J} \text { in total. }\end{array}$ & $\begin{array}{l}\text { The pulsed light was more effective than the } \\
\text { low-level continuous laser and the high power } \\
\text { laser in the MVC and in the delayed onset muscle } \\
\text { soreness. For muscle damage the high power } \\
\text { laser was more effective. }\end{array}$ \\
\hline
\end{tabular}

Legend: R - red laser; IR - infrared laser; J - joule; LLLT - Low Level Laser Therapy; MR - maximum repetition; MVC - maximum voluntary contraction; LED - Light Emitting Diode.

Figure 3. Main findings of the literature on the application of low-level laser for the improvement of muscle performance 
The sample of this study consisted, then, of 27 articles published in the years $2008^{11}, 2009^{12-14}$, $2010^{2,15,16}, \quad 2011^{17}, \quad 2012^{18-20}, \quad 2013^{10,21,22}, \quad 2014^{23-26}$, $2015^{27,28}, 2016^{29-34}$ and $2017^{35}$. Of these, only three $(11.1 \%)$ were published in Portuguese ${ }^{10,16,28}$. The other ones are in English, but all of them (100.0\%) were produced by Brazilian authors.

The size of the samples in the studies ranged from $8^{13}$ to $60^{30}$ individuals, age group from $17^{13}$ to 70 years ${ }^{22,33}$. Regarding the participants' characteristics, 26 (96.3\%) articles were conducted with healthy individuals and only 1 (3.7\%) article evaluated the influence of the laser on the functional capacity of hospitalized patients with a history of heart failure ${ }^{29}$. Still regarding the sample characterization, $3(11.1 \%)$ studies had as specific objectives the evaluation of the performance of elderly women $^{22,31,33}$. Of the total, $3(11.1 \%)$ presented skin tone as exclusion criterion, not including in the study

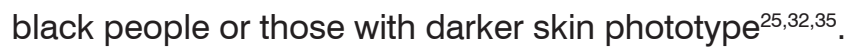

Among the objectives of the studies, the main investigated aspects were the action of the laser on muscle fatigue $2,11-13,15,16,18,20-23,25,26,28,29,33,35$ and on the gain of strength and/or the performance in a given activity $2,10,14,16,17,19,20,24,25,27,28,30-35$. The comparison of the laser effects with other therapeutic light sources was also the objective of $3(11.1 \%)$ studies $^{10,13,35}$, and 1 (3.7\%) work compared the effects of the red and infrared wavelengths on the muscle fatigue ${ }^{18}$.

The most used wavelength was infrared, being the choice of 23 (85.2\%) 2,10,12-15,17,19-27,29-35 surveys. Only $3(11.1 \%)^{11,16,28}$ used the red one. Besides these, 1 (3.7\%) author used the two wavelengths separately to compare them ${ }^{18}$. No study used red and infrared wavelengths simultaneously.

The total doses used were calculated according to the amount of joules $(\mathrm{J})$ per application point multiplied by the number of points, and it ranged from $1.92 \mathrm{~J}^{28}$ to $300 \mathrm{~J}^{32}$. The minimum value used in one point was 0.24 $\mathrm{J}^{28}$ and the maximum was $50 \mathrm{~J}^{32}$. The number of points was between $2^{2,13}$ and "approximately" 29 points ${ }^{25}$.

Regarding the application points, in all studies the application was carried out with contact and along the extension of the evaluated muscle or the one responsible for the requested function.

Concerning the results, 5 (18.5\%) studies did not find significant answers in at least one of the researched variables ${ }^{13,21,28,34,35}$. The others found statistically significant responses in at least one of the evaluated variables, with improvement in fatigue levels, strength gain and endurance, showing that low-level laser can be a capable therapy of optimizing muscle performance.

Muscle performance was assessed by the best performance of the proposed task, by cardiorespiratory assessment, by increasing the exercise load or also by the number of repetitions. Regarding fatigue, this factor was considered in the studies with reference to the execution time, the biochemical markers (such as lactate and creatine kinase protein levels) and the electromyographic signal. As these are not the objectives of this research, the assessment methods and instruments and the proposed physical tests were not discussed here. Such analyzes would be hampered mainly because they are specific knowledge of areas beyond the field of competence of Speech-language pathology.

The investigation of laser as a therapy to improve muscle performance is quite recent, as evidenced by the oldest article published, from $2008^{11}$. This justifies the difficulties in finding ideal dosimetric parameters to achieve the different proposed objectives, being this limitation discussed by the authors of all analyzed works. It is believed that the fact that all works have Brazilian authorship may be related to the authors' research lines. It was noted that the same authors participated in several works, which led to very similar methodological designs.

In regard to the characterization of the sample, most studies included healthy individuals, and only one investigated the effects on hospitalized patients ${ }^{29}$. This finding was expected because, when investigating new approaches or therapeutic tools, it is interesting to understand their functioning in healthy subjects and then evaluate their effectiveness in different clinical conditions. Regarding the age, most studies adopted some range between 17 and 36 years. One study presented intervals from 35 to 65 years $^{29}$ and only three, which intended to evaluate the effects in the elderly, adopted as inclusion criteria the age between 60 and 70 years $^{22,31,33}$.

None of the articles approached possible contraindications for laser therapy as exclusion criteria, not even those described in the manufacturers' manuals. Only factors that could influence the researched variables were taken into consideration and three studies excluded dark skinned participants from the sample $e^{25,32,35}$ claiming that, because melanin is a chromophore, these subjects could have greater sensitivity to light. 
Concerning the sample size, $\mathrm{N}$ was very reduced in all studies, with number of participants ranging between $8^{26}$ and $60^{30}$ subjects. All the authors mentioned that this amount may have intervened in the achieved results.

As for the dosimetric parameters, a great variation was observed. The most used wavelength was the infrared one, being the option of most studies ${ }^{2,10,12-}$ 15,17,20-27,29-35. The main justification was the reference to previous studies and the fact that this wavelength presents greater penetrability in the human tissue.

Just three studies ${ }^{11,16,28}$ used only the red wavelength. One of them did not obtain significant responses, but it was also the one that used the lowest dose $^{28}$. In another study ${ }^{11}$, the authors reported that the choice for red was due to the availability of the equipment, recognizing that infrared would have been the ideal choice, although they found a significant increase in the number of repetitions. The third study that used the visible wavelength ${ }^{16}$ also observed an improvement in the peak torque (maximum functional muscle strength), but without effects on muscle fatigue. According to the authors, this may be due to the light's range depth, which allowed an energetic input for better contraction performance. However, its limited range was not enough for the accumulated energy to influence the fatigue index. The work that used the two wavelengths separately, for the purpose of comparing them ${ }^{18}$, found an improvement in the peak torque for both, without statistical difference between them. Given the justification based on the light range and considering the superficiality of the facial muscles, it is expected that there is no significant difference between these wavelengths when the effects on facial muscles are investigated.

The dose was a parameter that had great variation between the studies, especially considering the number of points and the total dose. The most used doses per point were $7 \mathrm{~J}^{21,22,31,33}$ and $30 \mathrm{~J}^{2,15,19,27,32,35}$. However, it was not possible to establish a correlation between the dose used and the results obtained, because, for the same dose, different results were found. This parameter is still the biggest challenge for the elaboration of protocols for laser use not only in muscle performance but also in other areas.

Regarding the application techniques, all were performed with tip contact on the skin and on the target muscle. The number of points varied, but in all studies there was concern that irradiation were carried out to the full extent of the target muscle. As there was a wide variety of equipment models and, consequently, in the area of light output, the number of points was also quite diverse. In 4 (14.8\%) studies ${ }^{17,20,31,34}$ the application was performed after the exercise protocols. In 2 (7.4\%) studies ${ }^{24,26}$ the irradiation occurred between the series and, in the other ones $(77,8 \%)$, the laser was applied before the activity. The most used justification for the application after the exercise was based on the fact that the laser assists in muscle recovery after exertion. However, it was observed that this parameter was not determinant for therapeutic success, since it did not guarantee significant responses in all studies. The application before the exercises seems to be related to the increase of ATP synthesis provided by the photobiomodulatory action, which favors the energetic contribution to the muscular work during the activity.

The other parameters, such as power, energy density and intensity density were not discussed here because they are measures related to equipment models and not programmed by the researcher.

In general, it was observed by the results found that low-level laser intervenes in the muscle performance, improving the fatigue index, increasing strength gain, improving chemical markers and also increasing muscle endurance. However, due to the methodological diversity, it becomes difficult to identify effective parameters for obtaining these results.

\section{CONCLUSION}

This review allowed to identify the main dosimetric parameters for the application of low-level laser in the muscle performance. A predominance of infrared wavelength in the studies, with application in the extension of the muscle in equidistant points, was observed. It was not possible to correlate the results obtained with the dose used, but it was observed that low-level laser photobiomodulation is a potential tool for optimizing muscle performance and reducing fatigue levels, following intense activities.

\section{REFERENCES}

1. Leal-Junior ECP, Vanin AA, Miranda EF, de Carvalho P de T, Dal Corso S, Bjordal JM. Effect of phototherapy (low-level laser therapy and lightemitting diode therapy) on exercise performance and markers of exercise recovery: a systematic review with meta-analysis. Lasers Med Sci. 2015;30(2):925-39.

2. Leal Junior EC, Lopes-Martins RA, Frigo L, DeMarchi T, Rossi RP, de Godoi V et al. Effects of 
low-level laser therapy (LLLT) in the development of exercise-induced skeletal muscle fatigue and changes in biochemical markers related to postexercise recovery. J Orthop Sports Phys Ther. 2010;40(8):524-32.

3. Vanin AA, Miranda EF, Machado CS, de Paiva $\mathrm{PR}$, Albuquerque-Pontes GM, Casalechi $\mathrm{HL}$ et al. What is the best moment to apply phototherapy when associated to a strength training program? A randomized, double-blinded, placebo-controlled trial. Lasers Med Sci. 2016;31 (8):1555-64.

4. Shinozaki EB, Santos MBF, Okazaki LK, Marchini L. Clinical assesment of the efficacy of low level laser therapy on muscle pain in women with temporomandibular dysfunction, by surface electromyography. Braz J Oral Sci. 2010;9(4):434-8.

5. Santos MTBR, Nascimento KS, Carazzato S, Barros AO, Mendes FM, Diniz MB. Efficacy of photobiomodulation therapy on masseter thickness and oral health-related quality of life in children with spastic cerebral palsy. Lasers MedSci. 2017;32(62):1279-88.

6. Karu T. Photobiological fundamentals of low-power laser therapy. IEEE J Quantum Electron. 1987;23(10):1703-17.

7. Lane N. Cell biology: power games. Nature. 2006;443(7114):901-3.

8. Karu TI, Pyatibrat LV, Afanasyeva NI. Cellular effects of low power laser therapy can be mediated by nitric oxide. Lasers Surg Med. 2005;36(4):307-14.

9. Sousa MVP. What is low-level laser (light) therapy? In: Hamblin MR, Sousa MVP, Agrawal T (eds). Handbook of low-level laser therapy. New York: Pan Stanford; 2016. p. 1-16.

10. Muñoz ISS, HauckI LA, Nicolau RA, Kelencz CA, Maciel TS, de Paula Júnior AR. Effect of laser vs LED in the near infrared region on the skeletal muscle activity: clinical study. Rev Bras EngBioméd. 2013;29(3):262-8.

11. Leal Junior ECP, Lopes-Martins RAB, Dalan F, Ferrari M, Sbabo FM, Generosi RA et al. Effect of 655-nm low-level laser therapy on exercise-induced skeletal muscle fatigue in humans. Photomed Laser Surg. 2008;26(5):419-24.

12. Leal Junior ECP, Lopes-Martins RAB, Vanin AA, Baroni BM, Grosselli D, De Marchi Tet al. Effect of $830 \mathrm{~nm}$ low-level laser therapy in exercise-induced skeletal muscle fatigue in humans. Lasers Med Sci. 2009;24(3):425-31.
13. Leal Junior ECP, Lopes-Martins RAB, Baroni BM, De Marchi T, Rossi RP, Grosselli D et al. Comparison between single-diode low-level laser therapy (LLLT) and LED multi-diode (cluster) therapy (LEDT) applications before high-intensity exercise. Photomed Laser Surg. 2009;27(4):617-23.

14. Leal Junior EC, Lopes-Martins RA, Baroni BM, De Marchi T, Taufer D, Manfro DS et al. Effect of $830 \mathrm{~nm}$ low-level laser therapy applied before high-intensity exercises on skeletal muscle recovery in athletes. Lasers MedSci. 2009;24(6):857-63.

15. Baroni BM, Leal Junior ECP, De Marchi T, Lopes $A L$, Salvador M, Vaz MA. Low level laser therapy before eccentric exercise reduces muscle damage markers in humans. Eur J Appl Physiol. 2010;110(4):789-96.

16. Leal Junior ECP, Nassar FR, Tomazoni SS, Bjorda JM, Lopes-Martins RAB. Low-level laser therapy enhances muscular performance as measured by isokinetic dynamometry in humans. FisioterPesqui. 2010;17(4):317-21.

17. Ferraresi C, Oliveira TB, Zafalon LO, Reiff RBM, Baldissera V, Perez SEA et al. Effects of low level laser therapy (808 $\mathrm{nm}$ ) on physical strength training in humans. Lasers Med Sci. 2011;26(3):349-58.

18. De Almeida P, Lopes-Martins RAB, De Marchi T, Tomazoni SS, Albertini R, Corrêa JCF et al. Red $(660 \mathrm{~nm})$ and infrared (830 nm) low-level laser therapy in skeletal muscle fatigue in humans: what is better? Lasers Med Sci. 2012;27(2):453-8.

19. Marchi T, Leal Junior EC, Bortoli C, Tomazoni SS, Lopes-Martins RA, Salvador M. Low-level laser therapy (LLLT) in human progressive-intensity running: effects on exercise performance, skeletal muscle status, and oxidative stress. Lasers MedSci. 2012;27(1):231-6.

20. Vieira WH, Ferraresi C, Perez SE, Baldissera V, Parizotto NA. Effects of low-level laser therapy $(808 \mathrm{~nm})$ on isokinetic muscle performance of young women submitted to endurance training: a randomized controlled clinical trial. Lasers Med Sci. 2012;27(2):497-504.

21. Higashi RH, Toma RL, Tucci HT, Pedroni CR, Ferreira PD, Baldini G et al. Effects of low-level laser therapy on biceps braquialis muscle fatigue in young women. Photomed Laser Surg. 2013;31(12):586-94.

22. Toma RL, Tucci HT, Antunes HK, Pedroni CR, Oliveira AS, Buck I et al. Effect of $808 \mathrm{~nm}$ low-level laser therapy in exercise-induced skeletal muscle 
fatigue in elderly women. Lasers Med Sci. 2013;28(5):1375-82.

23. Alves MAS, Pinfildi CE, Nilsen Neto L, Lourenço RP, Azevedo PHSM, Dourado VZ. Acute effects of low-level laser therapy on physiologic and electromyographic responses to the cardiopulmonary exercise testing in healthy untrained adults. Lasers MedSci. 2014;29(6):1945-51.

24. Felismino AS, Costa EC, Aoki MS, Ferraresi C, Lemos TMAM, Vieira WHB. Effect of low-level laser therapy $(808 \mathrm{~nm})$ on markers of muscle damage: a randomized double-blind placebo-controlled trial. Lasers MedSci. 2014;29(3):933-8.

25. Maciel TS, Muñoz IS, Nicolau RA, Nogueira DV, Hauck LA, Osório RA et al. Phototherapy effect on the muscular activity of regular physical activity practitioners. Lasers Med Sci. 2014;29(3):1145-52.

26. Vieira WHB, Bezerra RM, Queiroz RA, Maciel NF, Parizotto NA, Ferraresi C. Use of low-level laser therapy $(808 \mathrm{~nm})$ to muscle fatigue resistance: a randomized double-blind crossover trial. Photomed Laser Surg. 2014;32(12):678-85.

27. Baroni BM, Rodrigues $R$, Freire $B B$, Franke RA, Geremia JM, Vaz MA. Effect of low-level laser therapy on muscle adaptation to knee extensor eccentric training. Eur J Appl Physiol. 2015;115(3):639-47.

28. Kakihata CMM, Malanotte JA, Higa JY, Errero TK, Balbo SL, Bertolini GRF. Influence of low-level laser therapy on vertical jump in sedentary individuals. Einstein. 2015;13(1):41-6.

29. Bublitz C, Renno AC, Ramos RS, Assis L, Sellera $\mathrm{CA}$, Trimer $\mathrm{R}$ et al. Acute effects of low-level laser therapy irradiation on blood lactate and muscle fatigue perception in hospitalized patients with heart failure-a pilot study. Lasers Med Sci. 2016:31(6):1203-9.

30. Souza CG, Borges DT, Macedo LB, Brasileiro JS. Low-level laser therapy reduces the fatigue index in the ankle plantar flexors of healthy subjects. Lasers MedSci. 2016;31(9):1949-55.

31. Toma RL, Vassão PG, Assis L, Antunes HK, Renno AC. Low level laser therapy associated with a strength training program on muscle performance in elderly women: a randomized double blind control study. Lasers Med Sci. 2016;31(6):1219-29.

32. Vanin A, De Marchi T, Tomazoni SS, Tairova O, Leão Casalechi H, Carvalho PTC et al. Pre-exercise infrared low-level laser therapy $(810 \mathrm{~nm})$ in skeletal muscle performance and postexercise recovery in humans, what is the optimal dose? A randomized, double-blind, placebo-controlled clinical trial. Photomed Laser Surg. 2016;34(10):473-82.

33. Vassão PG, Toma RL, Antunes HKM, Tucci HT, Renno ACM. Effects of photobiomodulation on the fatigue level in elderly women: an isokinetic dynamometry evaluation. Lasers MedSci. 2016;31(2):275-82.

34. Zagatto AM, Ramos SP, Nakamura FY, Lira FS, Lopes-Martins RA, Carvalho RLP. Effects of low-level laser therapy on performance, inflammatory markers, and muscle damage in young water polo athletes: a double-blind, randomized, placebo-controlled study. Lasers MedSci. 2016;31(3):511-21.

35. Marchi T, Schmitt VM, Fabro DS, Silva LL, Sene J, Tairova $\mathrm{O}$ et al. Phototherapy for improvement of performance and exercise recovery: comparison of 3 commercially available devices. J AthlTrain. 2017;52(5):429-38. 